\title{
HUBUNGAN ANTARA PENGETAHUAN DAN MINAT \\ WANITA PREMENOPAUSE TERHADAP SKRINING \\ INSPEKSI VISUAL ASAM ASETAT \\ ( Di BPM Lestari Ny. Joestina Desa Banyakan Kabupaten Kediri)
}

Soemarmi, SPd.M.Kes ${ }^{1}$, Desy Dwi Natalia ${ }^{2}$

Akademi Kebidanan Dharma Husada Kediri Jawa Timur

\begin{abstract}
ABSTRAK
Kanker serviks adalah kanker yang menyerang leher rahim, kenyataanya banyak yang belum memahami pengertian kanker serviks masalah yang sering terjadi adalah kurangnya pengetahuan dan minat untuk melakukan skrining IVA. Karena biasanya penderita datang ke dokter kebidanan dan kandungan sudah terlambat. Hal ini menyebabkan angka kematian akibat kanker serviks sangat tinggi. Tujan dari penelitian ini adalah untuk mengetahui pengetahuan dan minat wanita presmenopause terhadap skrining IVA di BPM Lestari Ny. Joestina Desa Banyakan Kecamatan Banyakan Kabupaten Kediri.

Desain pada penelitian ini mengunakan korelasional dengan pendekatan cross sectional. Tempat penelitian dilakukan di BPM Lestari Ny. Joestina di Desa Banyakan Kecamatan Banyakan Kabupaten Kediri. Populasi adalah wanita Premenopause sebanyak 30 responden. Teknik sampling menggunakan total sampling. Variabel bebas adalah pengetahuan wanita premenopause dan variabel terikat adalah minat wanita premenopause terhadap skrining IVA. Pengumpulan data dengan kuesioner. Pengelolahan data meliputi editing, coding, scoring, dan tabulating. Penelitian telah dilaksanakan pada tanggal 16-22 Mei. Hasil penelitian ini dianalisa menggunakan Spearman Rank.

Hasil penelitian menunjukan dari 30 orang responden Sebagian besar responden wanita premenopause 20 responden $(67,00 \%)$ memiliki pengetahuan yang cukup tentang skrining IVA Dan Sebagian besar responden wanita premenopause 26 responden $(87,00 \%)$ memiliki minat yang tinggi tentang skrining IVA. Kemudian dilakukan penghitungan dengan SPSS Hal uji spearmank rank diperoleh nilai $p$ value $=0,003<$ 0,05 (pada taraf signifikan 5\%), maka H1 diterima. Dengan keeratan hubungan cukup tinggi 0,523. Artinya ada hubungan antara pengetahuan dengan minat wanita premenopause terhadap skrining IVA sebagai deteksi dini kanker serviks.

Berdasarkan hasil penelitian dapat disimpulkan ada hubungan antara pengetahuan dan minat wanita premenopause terhadap skrining IVA. Dalam hal ini petugas kesehatan mempunyai peran penting untuk meningkatkan pengetahuan dan minat untuk segera melakukan skrining IVA sebagai deteksi dini kanker serviks.
\end{abstract}

Kata Kunci: Pengetahuan, Minat, Wanita Premenopause, Skrining IVA dan Kanker Serviks. 


\section{PENDAHULUAN}

Kanker serviks dapat menjadi ancaman bagi kaum wanita tua maupun muda. Banyak orang yang tidak tahu mengenai kanker serviks. Padahal banyak orang yang meninggal disebabkan oleh kanker serviks. Pada perkembangan kanker ini sangat sulit dideteksi. Biasanya kanker ini dapat berkembang pada wanita ketika mereka masih muda dan belum menikah atau telah memiliki anak.

Kanker serviks berkembang secara bertahap, tetapi progesif. proses terjadinya kanker ini dimulai dengan sel yang mengalami mutasi lalu berkembang menjadi sel displastik sehingga terjadi kelainan epitel yang disebut displasia. Dimulai dari displasia ringan, displasia sedang, displasia berat, dan akhirnya menjadi karsinoma in-situ (KIS), kemudian berkembang lagi menjadi karsinoma invasif. Tingkat displasia dan KIS dikenal juga sebagai pra-kanker. Dari displasia menjadi karsinoma in-situ diperlukan waktu 1-7 tahun, sedangkan karsinoma in-situ menjadi karsinoma invasif berkisar 3-20 tahun. (Aminati, 2013:27).

Sebenarnya apabila selama jeda tersebut dapat diketahui telah terjadi invasi kanker leher rahim maka hal tersebut dapat dicegah. Bila mengerti akan dapat menghentikan sel-sel yang tidak normal tersebut sebelum berubah menjadi kanker. Sel-sel yang abnormal tersebut dapat dideteksi dengan tes yang disebut screning. Sehingga semakin dini sel-sel abnormal terdeteksi, semakin rendahlah resiko seorang menderita kanker leher rahim. (Aminati, 2013:27).

Minat merupakan sumber motInspeksi Visual Asam Asetatsi yang mendorong orang untuk melakukan apa yang mereka inginkan bila mereka bebas memilih. Ketika seseorang menilai bahwa sesuatu akan bermanfaat, maka akan manjadi berminat, kemudian hal tersebut akan mendatangkan

(Suparyanto,2011). Seorang tenaga kesehatan harus bisa memberikan motInspeksi Visual Asam Asetatsi dan pengetahuan yang lebih agar setiap wanita lebih minat melakukan srining Inspeksi Visual Asam Asetat sebagai deteksi dini kanker serviks.

Menurut dr. Maringan DL tobing, secara klinis, kanker leher rahim prainvasif adalah keadaan tanpa keluhan dan dengan mata biasa tidak mungkin dapat dideteksi karena sering tampak sebagai leher rahim normal. Karenanya screning lesi pra-kanker sangat penting mengingat pengobatan memberi kesembuhan sampai $100 \%$. Sedangkan pada kanker invasif memberi hasil kurang memuaskan dengan harapan hidup 5 tahun antara 20-90\%. (Diananda, 2007:47).

Gejala seorang terinfeksi HPV memang tidak terlihat dan tidak mudah diamati. Cara paling mudah untuk mengetahuinya adalah dengan melakukan PAP smear test atau Papanocolaou sitologis leher rahim. Pemeriksaan sitologis saat ini populer dengan nama $P A P$ smear test yang diambil dari nama dokter yunani yang menemukan metode ini, yaitu George N.Papanocolaou, yang merancang metode mewarnai pulasan sampel sel-sel untuk diperiksa sekitar 50 tahun yang lalu. Namun dalam hal ini ada juga berbagai metode lainya untuk deteksi dini terhadap infeksi HPV dan kanker serviks diantaranya adalah Inspeksi Visual Asam Asetat. (Tilong, 2012:37).

Inspeksi Visual Asam Asetat merupakan cara sederhana untuk untuk mendeteksi kanker leher rahim sedini mungkin. Prosedur ini begitu sederhana sebab saat pemeriksaan tidak perlu ke laboratorium (Aminati, 2013:98). Inspeksi Visual Asam Asetat adalah metode yang lebih mudah, sederhana dan mampu terlaksana hingga screening dapat dilakukan dengan cakupan yang lebih luas (Tilong, 2012:45).

Inspeksi Visual Asam Asetat sebagai deteksi dini kanker dilakukan dengan mengambil cairan yang berada pada leher rahim, tes Inspeksi Visual Asam Asetat dilakukan dengan mengusap atau mengoles leher rahim (servix) dengan asam asetat 3$5 \%$ dan larutan iodium lugol dengan bantuan lidi wotten. Cara ini dilakukan untuk melihat perubahan warna yang terjadi pasca olesan. Perubahan warna bisa 
diamati setelah 1-2 menit. (Savitri, 2015:244). Leher rahim dikatakan abnormal apabila pasca pengolesan mengalami prubahan warna menjadi putih (aceto white ephitelium) dengan batas yang tegas. Jika tidak ada perubahan warna maka leher rahim dianggap normal. Beberapa wanita yang direkomendasikan untuk memilih deteksi dini Inspeksi Visual Asam Asetat (Savitri, 2015:245).

Berdasarkan data yang diperoleh dari badan kesehatan dunia (WHO) diketahui terdapat 493.245 jiwa per tahun penderita kanker serserviks baru di dunia dengan angka kematian karena kanker ini sebanyak 273.505 jiwa per tahun (Emilia, 2010). WHO menyatakan, saat ini penyakit kanker serviks menempati peringkat teratas diantara berbagai jenis kanker yang menyebabkan kematian pada perempuan didunia (Hasanudin, 2010).

Menurut Yayasan Kanker Indonesia saat ini penyakit kanker leher rahim menyebabkan korban meninggal sedikitnya 200.000 per tahun. "Sebanyak 52 juta dari sekitar 115 juta perempuan Indonesia beresiko terkena kanker rahim (serviks) karena berbagai alasan". Dari seluruh penderita kanker Indonesia, sepertiganya adalah penderita kanker serviks ( Rozi, 2013:15). Berdasarkan penelitian yang dilakukan oleh WHO, setiap harinya di Indonesia ada 40 orang wanita terdiagnosa dan 20 wanita meninggal karena kanker serviks (Rozi, 2013:13).

Kejadian kanker serviks di Indonesia cukup tinggi. Dari Departemen Kesehatan RI memperkirakan kejadian per tahun kanker serviks hingga 100 per penduduk Indonesia. Data ini mengenai distribusi kanker serviks menurut daerah di Indonesia, Surabaya 37,51\% (Aminati, $2013: 35)$.

Kanker serviks merupakan kanker dengan jumlah paling banyak kedua di seluruh dunia, dengan jumlah 500.000 kasus baru dan 250.000 kematian tiap tahunya. Sebagian besar kasus kejadian dan kematian dari kanker serviks terjadi pada kelompok umur 45-55 tahun dengan Age Spesific Death Rate (ASDR) 29,5\% per 100.000 perempuan pada umur $45-55$ tahun. Didapatkan frekuensi tertinggi pada kelompok premenopause yaitu pada bulan juli 2009 sampai dengan juni 2010 sebanyak 448 kasus (8,38\%). Stadium kanker serviks terbanyak stadium IIIb dengan umur $>55$ tahun. (Kementrian Kesehatan Republik Indonesia, 2015).

Jawa Timur merupakan salah satu provinsi di Indonesia yang mempunyai jumlah kasus kanker serviksyang cukup tinggi. Di Jawa Timur sebanyak 11,25\% wanita menderita kanker serviks. Berdasarkan data dinas kesehatan provinsi Jawa Timur, kasus kanker serviks terjadi di 29 kabupaten dan 8 kota di Jawa Timur pada tahun 2011 dengan jumlah total sebesar 1844 kasus. (Dinas Kesehatan Provinsi Jawa Timur, 2011).

Kasus kanker serviks di kota Kediri cukup banyak yaitu pada tahun 2005 sebanyak 170 kasus, 2006 sebanyak 125 kasus, 2007 sebanyak 139 kasus, dan pada tahun 2008 sebanyak 83 kasus (Dinas Kesehatan Kota Kediri, 2010).

Secara umum, penyebab terjadinya kanker serviks diakibatkan karena gaya hidup yang salah. Baik gaya hidup keseharian maupun cara memperlakukan organ reproduksi wanita yang salah. Karena itu penyakit ini tak mengenal usia.

Selain itu masih ada faktor lain yang beresiko menjadi penyebab kanker serviks. Misalnya kebiasaan merokok, keputihan yang dibiarkan terus menerus, terkena PMS, penggunaan pembalut yang mengandung dioksin, kurang menjaga kebersihan organ reproduksi, melakukan seksual di usia muda $<16$ tahun dan berganti-ganti pasangan. (Savitri, 2015:123)

Berdasarkan kejadian tersebut setiap wanita mempunyai resiko terkena kanker serviks dan menjadi salah satu penyebab kematian tertinggi pada wanita, untuk mencegah adanya kanker serviks, sebaiknya setiap pasangan usia subur, terutama yang sudah menikah melakukan pemeriksaan dini secara rutin karena sifat dari kanker serviks gejala awalnya tidak diketahui. (Savitri, 2015:45). Sehingga seorang wanita seyoganya tahu akan pentingnya deteksi dini kanker serviks karena dapat terdeteksi secara tepat. 
Pada bulan April 2016 dilakukan penyuluhan Di BPM Lestari Ny. Joestina. Desa Banyakan Kecamatan Banyakan Kabupaten Kediri mengenai kanker serviks dan cara deteksi dini. Namun sampai saat ini minat wanita premenopause di wilayah tersebut masih sangat rendah untuk melakukan deteksi dini kanker serviks khususnya Inspeksi Visual Asam Asetat. Berdasarkan studi pendahuluan yang di lakukan peneliti tanggal 12 Mei 2016 didapatkan hasil dari 10 wanita premenopause, diperoleh data 2 (20\%) wanita premenopause yang mengetahui dan sudah melaksankan pemeriksaan Inspeksi Visual Asam Asetat, dan 8 (80\%) wanita premenopause mengetahui tentang pemeriksaan Inspeksi Visual Asam Asetat namun tidak berminat melakukan pemeriksaan Inspeksi Visual Asam Asetat.

\section{METODE}

Rancangan penelitian yang digunakan dalam penelitian ini adalah rancangan penelitian korelasional (hubungan/asosiasi). Penelitian korelasional bertujuan mengungkapkan hubungan korelatif antara variabel. Pada penelitian ini menggunakan pendekatan Cross sectional. Populasi yang digunakan dalam penelitian ini adalah seluruh wanita pre menopause di Di BPM Lestari Ny. Joestina Desa Banyakan Kecamatan Banyakan Kabupaten Kediri dan populasinya sebanyak 30 responden. Pada penelitian ini sampel yang diambil yaitu seluruh wanita premenopause Di BPM Lestari Ny. Joestina Desa Banyakan Kecamatan Banyakan Kabupaten Kediri dan Sampelnya sebanyak 30 responden. Dalam penelitian ini, peneliti menggunakan teknik total sampling. Instrumen yang digunakan adalah kuesioner.

\section{HASIL}

a. Pengetahuan Wanita Premenopause terhadap Skrining Inspeksi Visual Asam Asetat.

\begin{tabular}{|c|c|c|c|}
\hline No. & Pengetahuan & Frekuensi & Prosentase (\%) \\
\hline 1 & Baik & 4 & 13,00 \\
\hline 2 & Cukup & 20 & 67,00 \\
\hline 3 & Kurang & 6 & 20,00 \\
\hline & Total & 30 & 100,00 \\
\hline
\end{tabular}

Berdasarkan tabel I dapat diketahui bahwa pengetahuan pada 30 responden wanita premenopause didapatkan 20 responden $(67,00 . \%)$ pengetahuan cukup. Didapatkan 6 responden $(20,00 . \%)$ dengan pengetahuan kurang dan didapatkan 4 responden $(13,00 . \%)$ dengan memiliki pengetahuan baik.

b. Minat Wanita Premenopause terhadap Skrining Inspeksi Visual Asam Asetat.

\begin{tabular}{|c|c|c|c|}
\hline No & Kriteria Minat & $\boldsymbol{\Sigma}$ & $\mathbf{\%}$ \\
\hline 1 & Tinggi & 26 & 87,00 \\
\hline 2 & Sedang & 4 & 13,00 \\
\hline 3 & Rendah & 0 & 0,00 \\
\hline
\end{tabular}

Berdasarkan tabel II dapat diketahui bahwa minat pada 30 responden wanita premenopause didapatkan $26(87,00 \%)$ minat tinggi. 
c. Hubungan Pengetahuan dan Minat Wanita Premenopause terhadap Skrining Inspeksi Visual Asam Asetat.

\begin{tabular}{|c|c|c|c|c|c|c|c|}
\hline \multirow{2}{*}{ Minat } & \multicolumn{2}{|c|}{ Tinggi } & \multicolumn{2}{c|}{ Sedang } & \multicolumn{2}{c|}{ Rendah } & \multirow{2}{*}{$\Sigma$} \\
\cline { 2 - 7 } Pengetahuan & $\Sigma$ & $\%$ & $\Sigma$ & $\%$ & $\Sigma$ & $\%$ & \\
\hline Baik & 4 & 16,66 & 0 & 0,00 & 0 & 0,00 & 4 \\
\hline Cukup & 20 & 67,00 & 4 & 13,00 & 0 & 0,00 & 24 \\
\hline Kurang & 6 & 13,00 & 0 & 0,00 & 0 & 0,00 & 6 \\
\hline Total & \multicolumn{3}{|c|}{26} & 4 & \multicolumn{2}{|c|}{0} & 30 \\
\hline
\end{tabular}

Berdasarkan tabel III diatas menunjukan dari 30 responden yang diteliti didapatkan 20 responden $(67,00 \%)$ berpengetahuan cukup dengan minat tinggi 26 responden $(87,00 \%)$.

Berdasarkan hasil uji statistik menggunakan SPSS menggunakan analisa spearmank rank diperoleh pengetahuan correlation 1.000 dan minat 523 niai dari sig (2-tailed) 003 dan $\mathrm{N}=30$ sehingga hasil nilai $\mathrm{p}$ value $=0,003<0,05$ (pada taraf signifikan 5\%), maka H1 diterima. Artinya ada hubungan antara pengetahuan dengan minat skrining Inspeksi Visual Asam Asetat. 


\section{DISKUSI}

\section{Pengetahuan Wanita Premenopause terhadap Skrining Inpeksi Visual Asam Asetat di BPM Lestari Ny. Joestina Desa Banyakan Kecamatan Banyakan Kabupaten Kediri.}

Berdasarkan hasil penelitian pada tabel dapat diketahui bahwa dari 30 responden didapatkan 20 responden $(67,00 \%)$ berpengetahuan cukup, terhadap skrining Inspeksi Visual Asam Asetat. Dibuktikan dengan soal kuesioner sebanyak 24 untuk pengetahuan.

Pengetahuan adalah kesan didalaam pikiran manusia sebagai hasil penggunaan panca inderanya. Pengetahuan atau kognitif merupakan domain yang sangat penting untuk terbentuknya tindakan seseorang (overt behavior) karena dari pengalaman dan penelitian terbukti bahwa perolaku yang didasari oleh pengetahuan (Notoatmojo, 2012:138).

Dari penjelasan diatas dapat diketahui bahwa seseorang yang mempunyai pengetahuan akan lebih memahami dan mudah menerima dengan ilmu atau perilaku baru yang ada disekitarnya. Pengetahuan yang baik mempengaruhi cara berfikir individu terhadap materi yang disampaikan dalam pemberian kuesioner tentang skrining Inspeksi Visual Asam Asetat. Namun, terdapat kemungkinan lain yang menyebabkan rendahnya pengetahuan individu tentang skrining Inspeksi Visual Asam Asetat.

2. Minat Wanita Premenopause terhadap Skrinig Inspeksi Visual Asam Asetat di Desa Banyakan Kecamatan Banyakan Kabupaten Kediri.

Berdasarkan tabel dari hasil penelitian yang telah dilakukan di BPM Lestari Ny. Joestina di Desa Banyakan Kecamatan Banyakan
Kabupaten Kediri terdapat 30 responden. Didapatkan sebagian besar 26 responden $(87,00 \%)$ memiliki minat tinggi untuk melakukan pemeriksaan Inspeksi Visual Asam Asetat, 4 responden $(13,00 \%)$ memiliki minat sedang. Dari data tersebut diketahui bahwa minat wanita premenopause terhadap skrining Inspeksi Visual Asam Asetat sebagai deteksi dini kanker serviks di BPM Lestari Ny. Joestina di Desa Banyakan Kecamatan Banyakan Kabupaten Kediri memiliki minat tinggi.

Minat adalah suatu fungsi hidup kejiwaan manusia dapat diartikan sebagai aktivitas psikis dan mengandung usaha aktif yang berhubungan dengan pelaksanaan suatu tujuan (Ahmadi,2009:112).

Kondisi yang mempengaruhi minat menurut Crowand Crow (1982) dalam purwanto (2004) salah satunya adalah pendidikan. Menurut (Mudyaharjo, 2008) jenjang pendidikan adalah tingkatan pendidikan persekolahan yang berkesinambungan atara satu jenjang dengan jenjang yang lainya. Jenjang pendidikan yang termasuk jalur pendidikan sekolah terdiri dari pendidikan dasar, pendidiakn menengah, dan pendidikan tinggi (Suparyanto, 2011).

Dilihat dari kenyataan penelitian bahwa sebagian besar responden memiliki minat yang tinggi untuk melakukan pemeriksaan Inspeksi Visual Asam Asetat. Hal ini terjadi karena dipengaruhi oleh tingkat pendidikan para responden yang mayoritas berpendidkan terahir SMA.

3. Hubungan Pengetahuan antara Minat Wanita Premenopause terhadap Skrining Inspeksi Visual Asam Asetat di BPM Lestari Ny. Joestina di Desa Banyakan Kecamatan Banyakan Kabupaten Kediri. 
Dari tabel menunjukan bahwa dari 30 responden yang diteliti didapatkan sebagian besar responden yaitu 20 responden $\quad(67,00 \%)$ memiliki pengetahuan yang cukup dan minat yang tinggi yaitu 26 responden $(87,00 \%)$ dan sebagian kecil responden yaitu 6 responden $(20,00 \%)$ memiliki pengetahuan kurang dan tidak ada responden yang memiliki minat rendah. Hasil ujidengan spearman rank didapatkan hasil menentukan taraf signifikan yaitu $\alpha=0,003$ sehingga $\mathrm{H}_{0}$ ditolak $\mathrm{H}_{1}$ diterima. Dengan keeratan hubungan cukup tinggi yaitu sebesar 0,523 Artinya ada hubungan antara pengetahuan dan minat di BPM Lestari Ny. Joestina di Desa Banyakan Kecamatan Banyakan Kabupaten Kediri.

Pengetahuan itu sendiri dipengaruhi oleh faktor pendidikan formal, pengetahuan sangat erat hubunganya dengan pendidikan, dimanana diharapkan bahwa dengan pendidikan yang tinggi maka orang tersebut akan semakin luas pula pengetahuanya. Akan tetapi perlu ditekankan, bukan berati seorang yang berpendidikan rendah mutlak berpengetahuan rendah pula (Wawan dan Dewi, 2010;12).

Pada responden yang memiliki pengetahuan baik maka akan menimbulkan minat yang tinggi dalam dirinya sebab responden telah mengerti dengan yang dibahas. Responden akan semakin bersemangat dalam melakukan skrining Inspeksi Visual Asam Asetat sebagai deteksi dini kanker serviks sebab responden mengetahui akibat fatal yang disebabkan oleh kanker serviks.

\section{SIMPULAN}

1. Sebagian besar responden wanita premenopause memiliki pengetahuan yang cukup sebanyak 20 responden $(67,00 \%)$ tentang skrining IVA di BPM Lestari Ny. Joestina Desa Banyakan Kecamatan Banyakan Kabupaten Kediri.

2. Sebagian besar responden wanita premenopause memiliki minat yang tinggi sebanyak 26 responden $(87,00 \%)$ tentang skrining IVA di BPM Lestari Ny. Joestina Desa Banyakan Kecamatan Banyakan Kabupaten Kediri.

3. Berdasarkan hasil uji statistik menggunakan SPSS versi 2.1 dengan analisa spearmank rank diperoleh nilai $\mathrm{p}$ value $=0,003<$ 0,05 (pada taraf signifikan 5\%), maka $\mathrm{H} 0$ ditolak $\mathrm{H} 1$ diterima. Artinya ada hubungan antara pengetahuan dengan minat skrining IVA. Keeratan hubungan tergolong cukup tinggi. Di BPM Lestari Ny. Joestina di Desa Banyakan Kecamatan Banyakan Kabupatem Kediri. 


\section{DAFTAR PUSTAKA}

Aminati Dini. 2013. Cara bijak menghadapi dan mencegah kanker leher rahim (servik)s. Yogyakarta: Briliant Books.

Arikunto, 2006. Prosedur penelitian suatu pendekatan praktek. Jakarta : Rineka Cipta

Ariani Ayu Putri, 2014. Aplikasi Metodologi Penelitian Kebidanan dan Kedehatan Reproduksi. Yogyakarta: Nuha Medika

Diananda Rama, dr., 2008. Mengenal seluk beluk kanker. Jogjakarta : Kata Hati

Hidayat, A. Aziz Alimul. 2007. Metode Penelitian Keperawatan dan Teknik Analisis Data. Jakarta: Salemba Medika

2009. Metode

Penelitian Keperawatan Dan Teknik Analisis Data. Jakarta : Salemba

Medika. 2010. Metode

Penelitian Kebidanan Teknik Analisis

Data. Jakarta : Salemba Medika.

Marmi. 2014. Kesehatan Reproduksi. Yogyakarta: Pustaka Belajar

Meita Shanty, 2011. Silent Killer Diseases. Yogyakarta: Javalitera

Mubarak, W.I. 2011. Promosi Kesehatan Untuk Kebidanan. Jakarta : Salemba Medika.

Notoatmodjo, Soekidjo., 2007. Metode Penelitian Kesehatan. Jakarta : Rineka Cipta.

Proverawati Atikah, 2010. Menopause dan sindrome premenopause. Yogyakarta : Nuha Medika
Riduwan. 2010. Metode dan Teknik Menyusun Tesis. Bandung: Alfabeta

Sabrina Maharani, 2009. Mengenal 13 Jenis Kanker \& Pengobatannya. Yogjakarta : Kata Hati

Savitri Asrid, 2015. Kupas Tuntas Kanker Payudara Leher Rahim \& Rahim. Yogyakarta: Pustaka Baru Press

Smart Aqila, 2010. Kanker Organ Reproduksi. Yogyakarta : Aplus Books 